\section{THE STANDARDISATION OF SCREWS.}

THE question of standardising screw threads and limit gauges has long received the careful attention of engineers, and in Great Britain considerable advantage has accrued from the publication of an interim report (No. 20, April, 1905) of the Engineering Standards Committee, dealing with the form and pitches of screw-threads most suitable for general engineering purposes. Having regard to the fact that the Whitworth thread is in general use throughout the country, the committee does not recommend any departure from this form of thread. The existing. Whitworth series of pitches for screws from $\frac{1}{4}$ inch to 6 inches in diameter does not, however, satisfy all requirements, and the committee has drawn up tables of standard sizes which will doubtless meet with general adoption. For all sizes of screw threads below $\frac{1}{4}$ inch in diameter. the committee recommends the adoption of the pitches, sizes, and form of thread proposed by the British Association Small Screw Gauge Committee in 1884 .

In France an influential committee of the Société d'Encouragement pour 1'Industrie nationale, consisting of General Sebert and Messrs. Carpentier, Sauvage, Masson, Sartiaux, and Zetter, has devoted attention to the subject, and has published in the current issue of the Bulletin of the society a scheme for extending the international system to screws of less than 6 millimetres in diameter. The committee recommends the adoption, between the diameters of I millimetre and 5.5 millimetres inclusive, of twelve screws as shown in the following table:-

\begin{tabular}{|c|c|c|c|c|c|c|c|}
\hline $\begin{array}{c}\text { Diameter } \\
\mathrm{mm} \text {. }\end{array}$ & & & $\begin{array}{l}\text { Pitch } \\
\text { mm. }\end{array}$ & $\begin{array}{c}\text { Diameter } \\
\mathrm{mm} \text {. }\end{array}$ & & & $\begin{array}{l}\text { Pitch } \\
\text { mm. }\end{array}$ \\
\hline $\left.\begin{array}{l}I \cdot 0 \\
I \cdot 25\end{array}\right\}$ & $\cdots$ & $\cdots$ & 0.25 & $\left.\begin{array}{l}3.0 \\
3.5\end{array}\right\}$ & $\cdots$ & $\cdots$ & 0.60 \\
\hline $\begin{array}{l}1 \cdot 5 \\
1 \cdot 75\end{array}$ & $\cdots$ & $\cdots$ & $0 \cdot 35$ & $\begin{array}{l}4^{\circ} \mathrm{O} \\
4^{\circ} 5\end{array}$ & $\cdots$ & $\cdots$ & 0.75 \\
\hline $\left.\begin{array}{l}2.0 \\
2.5\end{array}\right\}$ & $\cdots$ & $\cdots$ & 0.45 & $\left.\begin{array}{l}5.0 \\
5.5\end{array}\right\}$ & .. & $\cdots$ & 0.90 \\
\hline
\end{tabular}

The six largest screws of this series are those first proposed by the second committee of the Chambre syndicale des Industries électriques. The screws of 2 millimetres and of 2.5 millimetres for which the pitch is 0.5 millimetre having proved too coarse, have received the pitch of 0.45 millimetre. The I millimetre screw has received the pitch of 0.25 millimetre in order to bring the new series into accord with the Thury series, which is used for very small screws. The scheme appears likely to be favourably received by the Swiss and German industries.

The initial accuracy of a helical surface, as distinct from the sectional form of the thread, is dependent upon the accuracy of the leading screw of the machine upon which it is cut, and thus the leading screw becomes a generating master-gauge which instead of being used solely for gauging is called upon to do work involving wear. The importance of maintaining the accuracy of these leading screws in connection with the production of the interchangeable parts of modern guns and gun mountings led to the appointment in November, I900, of a committee consisting of Mr. H. F. Donaldson, chief superintendent of the Royal Ordnance Factories, president, Mr. R. Matthews, Lieutenant A. T. Dawson, R.N., Mr. H. J. Chaney, Dr. R. T. Glazebrook, F.R.S., and Colonel H. C. L. Holden, R.A., F.R.S., to consider the provision of standard leading screws for screw-cutting lathes, and its report to the secretary of the Army Council has just been published. The committee finds that the only practical way to obviate the difficulty found in securing absolute interchangeability, even on short lengths of large screws, is to provide centrally special machinery for NO. I 870 . VOL. 72$]$ the supply of large screws of certified accuracy. Approval of funds for this purpose was accordingly sought and obtained. The machine, which was made by Messrs. Armstrong, Whitworth and Co., of Manchester, was designed to secure accuracy over 3 feet length of screw. Measurements made after the machine was installed in the special chamber erected for it at the National Physical Laboratory showed that the movement of the tool carriage did not vary from that produced by a true screw of the same reputed length by more than 0.0002 inch in its full length, and after insertion of a correcting cam by more than $0.000 \mathrm{~J}$ inch at any one point, and that corrected microscopic scale readings and independent end-measure readings dìd not differ by more than $0.000 \mathrm{I}$ inch at any point. The committee recommends that all accurate screws required for Government engineering work be supplied in future from screws originated from or corrected by the standard leadingscrew adjusting machine at the National Physical Laboratory, and that facilities be given to private firms to correct heavy screws of $\frac{1}{2}$-inch pitch by this machine. The house in which the machine is installed at the National Physical Laboratory presents many points of interest, as the greatest possible precautions have been taken to maintain uniformity of temperature and freedom from vibration.

\section{THE STERILISATION OF WATER IN THE FIELD.}

I $\mathrm{T}$ is well known that disease is more fatal to the soldier in a campaign than the bullets of the enemy. Thus in the South African campaign the total deaths from disease were almost exactly double those due to wounds in battle. The diseases which persistently dog the track of an army are typhoid or enteric fever, dysentery, and, in certain countries, cholera, and to these the principal mortaity is due.

As regards their incidence, much necessarily depends on the climatic and physical conditions of the country in which the war is being carried on. Both in the Spanish-American war and in the South African war typhoid fever proved a terrible scourge.

These diseases are usually largely water-borne, but it must be recognised are not exclusively so, and, therefore, attention to the water supply alone will not wholly prevent them. In the SpanishAmerican war, for instance, the commission which investigated the typhoid fever epidemics of the United States Army reported that infected water was not an important factor in its spread. The other agents concerned in the dissemination of this disease are dust and flies, blowing or carrying infection from infected latrines, and gastro-intestinal disturbance, the result of heat, fatigue, and bad food rendering the troops more vulnerable. It cannot be doubted, however, that a pure water supply would do much to lessen the incidence of typhoid fever and dysentery, and probably quite prevent cholera.

A pure water supply can partially be secured by three methods; (I) by a careful selection of the camping grounds and protection of the water supply from pollution; (2) by deep-driven artesian wells; and (3) by the sterilisation of the water; or a combination of these methods may in many instances be adopted. But whatever method is applied it must be remembered that soldiers parched with thirst will drink any water that comes in their way. As regards the first method, the selection of the camping grounds, \&c., it is reported that it has been adopted with considerable success by the Javanese in the present campaign; a corps of medical officers is sent on ahead to select the camping ground and survey the water supply; 